\title{
SWOT Analysis of the Cooperation between Enterprise and Vocational University for Aviation Electromechanical Equipment Maintenance Major
}

\author{
-Evidence from Liming Vocational University \\ XU Liping \\ College of Intelligent Manufacturing Engineering, \\ Liming Vocational University, \\ Quanzhou, China, 362000
}

\begin{abstract}
The aviation electromechanical equipment maintenance major is one of the major initiatives of the "made in China 2025" campaign. The cooperation between enterprises and vocational university is a key step in promoting the development of aviation electromechanical equipment maintenance major. We used SWOT analysis to analyze and identify the strengths, weaknesses, opportunities and threats of these programs. Our SWOT analysis provides an analytical framework for these partnership programs and our findings will be useful for vocational university and private enterprises that are entering in such partnership and promoting the integration of enterprises and educational institutions.
\end{abstract}

Keywords-SWOT; Aviation electromechanical equipment maintenance major; Integration of production and education; Professional training

\section{INTRODUCTION}

There were 229 airports, 3296 civil aviation aircrafts, 297 registered airlines and more than 70,000 students in civil aviation colleges in China by the end of 2017 [1]. Civil aviation industry has become a key strategic industry for China's economic and social development. The aviation electromechanical equipment maintenance has also become a fast-growing major in many vocational schools. It is one of the top ten initiatives of the Made in China 2025[2] campaign. According to the AABI standard, the university lab teaching equipment should meet the training objectives, and be in accordance with the actual equipment model and performance matrix used by enterprises [3]. However, due to the high cost of many specialized equipment, such as the fuel system, the wheel brake system, aircraft system testing apparatus, it is very difficult to simulate the actual operation procedures in a school lab. It becomes imperative for university to form close partnership with enterprises and to fulfill its educational objectives. Such partnership would allow students to participate in a field study and take full advantage of the enterprise's high quality equipment, experienced technicians, advanced maintenance process and standardized management methods" [4].
In this article, we use the partnership program at the Liming Vocational University as an example to analyze the current status of the Aviation Electromechanical Equipment Maintenance Major, and proposes a strategy of the integration of private enterprises and educational institutions.

\section{SWOT ANALYSIS}

SWOT analysis is a method under the situation analysis and is a commonly used qualitative analysis method. It is divided into internal environment (S-Strengths, W-Weaknesses) and external competition (O-Opportunities, T-Threats). It provides a comprehensive, systematic, and accurate analysis of the current market condition [5]. Based on the results of the SWOT analysis, one can formulate the corresponding strategy that optimally allocates available resources.

In order to provide a complete evaluation of the aviation electromechanical equipment maintenance major at Liming Vocational University, to further promote professional training, to better connect with local business and serve area economy, we conduct a SWOT analysis of our program. We analyze the Strength, the Weakness, the Opportunity and the Threats of the partnership between private enterprises and university. We examine the internal and external competitive environment to identify the strengths and weakness in our program and ways to improve our partnership program. Our goal is to educate skillful technicians that meet the continuing demand of the civil aviation industry.

\section{A. Strength analysis}

1) Mature University-Enterprise Partnership platform

Liming Vocational University continuously promotes the integration of real life experience and classroom education. The University encourages partnership between schools and enterprises and among various stakeholders [6]. Combing resources from private enterprises and universities, Liming Vocational University aims to fully integrate technical training with their real life applications and make our students the most sought after talents in the market. 


\section{2) Professional and experienced faculty}

Liming Vocational University has a team of professors with professional knowledge and rich teaching experience. They can apply diversified teaching methods and informationbased teaching methods to cultivate a good theoretical foundation for our students. They can also provide continuing education and training services for the personnel working in the aviation maintenance industry.

\section{3) Complete scientific research system}

Liming Vocational University is committed to improving the overall standard of its research and outreach programs. The university encourages its faculty to engage in high quality research and innovative studies. It encourages the faculty to actively participate in outreach services that may help industry and enterprises to solve technical problems in the real production process. The university has also a well-functioning incentive policy and management system to promote these objectives.

\section{4) A well-designed curriculum}

To work in the aviation electromechanical equipment maintenance industry one needs to have the professional knowledge, and understand the standard operation practice. In addition, one should be fully aware of all security protocol and professional ethics. Based on the general requirements of the industry, the university establish a training program and develop a curriculum that integrate certification in the regular course work. It sets up a curriculum that fully integrate experiential work and academic learning and a program that joins university with private enterprises.

\section{B. Weakness analysis}

1) Insufficient training equipment and space

The study of aviation electromechanical equipment maintenance requires significant investment in equipment and technology. The size of aviation equipment is often large and the university often lacks the necessary lab space to store the equipment for teaching and demonstration. Due to the restriction in funding and space, the school does not have the complete set of in-service aviation equipment to provide handson training and it is difficult to ensure the school teaching is exactly in line with real-life operation.

\section{2) Delay in adopting the latest technology}

The rapid development of aviation technology and equipment requires universities to constantly update their curriculum as well. Currently, the university has a delay in adopting the latest technology and the most recent teaching material. This will create a mismatch between our curriculum and the actual demands by the industry.

\section{3) Shortage of engineers and technicians}

University professors have more theoretical knowledge than practical skills. The lack of experience in the maintenance of aviation electromechanical equipment, and practical experience in enterprises make it difficult for effective classroom instruction. The practical training course is hard to deliver and there is often a gap between our classroom delivery and company expectation.

\section{4) Lack of off-campus training funds}

Students who major in aviation electromechanical equipment maintenance have a long training cycle and many subjects to cover and require a much higher funding for their training. Since the training equipment on campus is insufficient funding for the off-campus training becomes more important to ensure the quality of practical teaching. However, it is difficult to complete the practical training if the university makes no exception for this program and apply the uniform funding standard for the professional off-campus training.

\section{Opportunity analysis}

\section{1) Policy and industry support}

The office of the National Council formulated a policy to deepen the integration of private enterprises and vocational university. It explicitly proposed that vocational education should deepen the integration of production and education, and promote the organic linkage among the educational chain, talent chain, industrial chain and innovation chain [7]. Governments and educational agencies at all levels have come up with many policies and regulations to support the personnel training that integrates the production and education. Under this background, it is possible for the college and enterprise to build the program for sustainable development, to effectively ensure the quality of the enterprise's talent pool, and to enhance the ability for universities to serve the society and the industry.

\section{2) Expanding the construction of professional training} base

The use of resources and teaching facilities of schools and enterprises will greatly accelerate the construction of training bases inside and outside of schools. In accordance with the standards of civil aviation, special skill training program and vocational training program are introduced. These programs integrate teaching and production and combine in class learning with future employment. Such integration will improve the student interest and the training goal of the industry [8].

\section{3) Promoting double-qualified teacher}

Through the cooperation between university and enterprise, the college professor can regularly visit enterprises and learn the skills and operation norms of the maintenance of aviation electromechanical equipment. This will help to enrich the practical experience of the professor and to promote the benefit of being the double-qualified teachers.

4) Improving the ability of scientific research and application of college

Participation in enterprise technology research and development projects can help professors understand the development trends of advanced technology and new equipment in the aviation maintenance industry. It is beneficial for professors to study and stay up-do-date with the new technology and new tools. This will help them develop new projects and teaching material to improve the quality of our curriculum and research applications. The aviation maintenance enterprises can also benefit from participation by university professors who might have different insights. 


\section{Threat Analysis}

\section{1) Incomplete guarantee system}

Although governments and educational agencies at all levels are promoting the "integration of production and education", the corresponding policies have not been promulgated in time. "Responsibility, right, benefit" for the personnel training of the government, the college and the related industries in the vocational education is not clearly defined. The legal system of the industry enterprises to participate in vocational education still need to be further strengthened.

\section{2) Restrictions on technical secrecy}

Due to the unique characteristics of the aviation maintenance industry, the requirements for technical security and secrecy are high, and it is sometimes difficult to offer training outside of school. The development of the training base and scientific research service under the training program of "integration of production and education" is therefore limited to some extent.

\section{3) Lack of cross regional cooperation}

The maintenance of aviation electromechanical equipment requires very high level of professionalism. There are few maintenance enterprises in the region and few cross regional cooperation. Therefore, the number of aviation maintenance enterprises available to Liming Vocational University is low, and the choice of the schools to implement the integration of production and education is limited. It remains a challenging task to efficiently allocate limited resources to support the program growth.

4). Insufficient coordination between college and enterprise

The goal of a University is to serve the society, while enterprises aim to pursue profits. In the process of integrating production and education, the goal of a vocational university and the objective of an enterprise might not be aligned with each other. Enterprise lending equipment, places, technical personnel and so on might have a negative impact on its production efficiency. This will lower the incentives for the private enterprises to embrace the training program of "integration of production and education".

\section{STRATEGIES FOR PRODUCTION AND EDUCATION INTEGRATION PROGRAM}

TABLE I. SWOT ANALYSIS \& STRATEGIES

\begin{tabular}{|c|c|c|}
\hline & Opportunities & Threats \\
\hline Strategies & $\begin{array}{l}\text { (1).Policy and industry support } \\
\text { (2).Expanding the construction of professional } \\
\text { training base } \\
\text { (3).Promoting the double-qualified teacher } \\
\text { (4).Improving the ability of scientific research } \\
\text { and application of college }\end{array}$ & $\begin{array}{l}\text { (1).Incomplete guarantee system } \\
\text { (2).Restrictions on technical secrecy } \\
\text { (3).Lack of cross regional cooperation } \\
\text { (4).Insufficient coordination between college } \\
\text { and enterprise }\end{array}$ \\
\hline $\begin{array}{c}\text { Strengths } \\
\end{array}$ & \multirow{2}{*}{$\begin{array}{c}\text { Strength-Opportunity Strategy: } \\
\text { Promoting the construction of a training base } \\
\text { and improving the efficiency of private } \\
\text { enterprise }\end{array}$} & \multirow{2}{*}{$\begin{array}{l}\text { Strength-Threats Strategy: } \\
\text { International Joint Education Program }\end{array}$} \\
\hline $\begin{array}{l}\text { (1).Mature University-Enterprise Partnership } \\
\text { platform } \\
\text { (2).Professional and Experienced Faculty } \\
\text { (3).Complete scientific research system } \\
\text { (4).A well-designed Curriculum }\end{array}$ & & \\
\hline Weaknesses & $\begin{array}{l}\text { Weakness-Opportunity Strategy: } \\
\text { Introduction of industry specification and } \\
\text { optimizing the curriculum delivery system }\end{array}$ & $\begin{array}{l}\text { Weakness-Threats Strategy: } \\
\text { Improve the system of cooperation and } \\
\text { incentivize enterprises. }\end{array}$ \\
\hline
\end{tabular}

Based on the SWOT analysis of the integration of production and teaching in aviation electromechanical equipment maintenance major in Liming Vocational University, we provide the following suggestions and strategies .The analysis results are shown in "Table 1".

\section{A. Strength- Opportunity Strategy: Promoting the construction of a training base and improving the efficiency of private enterprise}

In the process of establishing partnership between school and enterprise, it is necessary to make a thorough feasibility study and consider the interests of all stakeholders. The program aims to achieve a win-win cooperation for the university and enterprises and strengthen the relationship between them. It will provide opportunities to set up training bases inside and outside of the school, and educate our students to become high-quality technicians with good professionalism.

\section{B. Weakness- Opportunity Strategy:Introducing industry specification and optimizing the curriculum delivery system}

In the process of setting up the aviation electromechanical equipment maintenance major course system, we fully consider the industry specification and the requirements of the enterprise post. Our curriculum integrates the CCAR-147, professional theory course and practice teaching, so that the graduates can obtain the academic degree and the basic aviation maintenance license at the same time. Our graduates with high technical skill and professionalism will provide a talent pool for the industry and save the cost of talent acquisition and training for industry enterprises. 


\section{Strength- Threats Strategy: International Joint Education Program}

International cooperation is a key achievement in China's higher education reform. The United States and Russia are in the international leading position in the field of Aeronautics and Astronautics. It is important to train the professional talents for the maintenance of aviation and electrical equipment to promote the internationalization of vocational education, promote the exchange of technology and cooperation and improve the international level of professional training.

\section{Weakness- Threats Strategy: Improving the system of cooperation and incentivize enterprises}

We should accelerate the revision of relevant laws and regulations, deepen the integration of production and education, and make clear the responsibility, rights and benefits of cultivating technical and technical talents by school enterprise cooperation, and improve the legal security level of school enterprise cooperation. The government agencies should give tax incentives and financial subsidies to provide incentives for enterprises to participate in the training program of "integration of production and education", and encourage enterprises and vocational colleges to become Dual Subjects for training the maintenance professionals of aviation electromechanical equipment.

\section{CONCLUSION}

Aviation electromechanical equipment maintenance major professional construction investment is large and difficult. The integration of production and education is an effective way for this major to grow effectively. This paper makes a comprehensive analysis of the strength, weakness, opportunities and threats of current aviation electromechanical equipment maintenance major professional training program, and proposes effective strategies. Our analysis provides useful insights for aviation electromechanical equipment maintenance major professional development and talent training.

\section{REFERENCES}

[1] China Civil Aviation Administration, "2017 civil aviation industry development statistics bulletin" [N], China Civil Aviation News, 20185-23( 003). (In Chinese)

[2] Yu Zhijing, Liu Hai, Yue Jinfeng, Li Yujing, Cheng Yu, Zhang Qiwu, "On the Manufacturing 2025 Strategy in China and Technical Skills Talents Training"' $\mathrm{J}]$, Vocational and Technical Education, 2015,36(21):10-24. (In Chinese)

[3] AABI, "AABI international forms \& publications" [EB/OL], http://www.aabi.aero/forms.html.

[4] ZHANG Peng, SUN Jun-qing, Li Zhong-hua, ZHANG Xue, GAN Na, "Pilot study of engineering education reform based on international aviation programs accreditation criteria"'J], Journal of Civil Aviation University of China, 2012,30(04):33-37. (In Chinese)

[5] MA Kang, SHI Chuan-xin, PEI Dong-li, "A research on Cooperative Laboratory Conducted by Universities and Companies Based on AHPSWOT'[J], Research and Exploration in Laboratory, 2016,35(08):241245. (In Chinese)

[6] Wang Songbai,'Deepen the integration of production and education and cultivate urgently needed talents in the region" [N], China Education Daily, 2017-08-28(003). (In Chinese)

[7] Fang Xujun, "The logic and Enlightenment of integration of production and education in Vocational Education under the policy context" [J], Chinese Vocational and Technical Education, 2018(12):13-18+55. (In Chinese)

[8] Xu Xing, Song Wenxue, "Customized talent training program under the mode of school enterprise cooperation education" [J], Chinese Vocational and Technical Education, 2008(24):12-14. (In Chinese) 